\title{
PEMBELAJARAN AKUNTANSI KEUANGAN DENGAN MODEL PEMBELAJARAN WORDSQUARE
}

\author{
Fatmawarni dan Aswin Bancin \\ Pendidikan Akuntansi Fakultas Keguruan dan Ilmu Pendidikan \\ Universitas Muhammadiyah Sumatera Utara \\ (Email: Fatmawarni010@gmail.com)
}

\begin{abstract}
Abstrak
Penelitian ini diawali dengan adanya fenomena yang terjadi pada mahasiswa, dimana hasil belajar akuntansi khususnya dalam menyusun laporan keuangan menunjukkan hasil yang belum memuaskan, terutama dalam hal melakukan pencatatan aktivitas ekonomi pada perusahaan. Salah satu dalam penyusunan laporan keuangan perlu dilakukan adalah pencatatan yaitu proses menjurnal, Berdasarkan hasil penelitian terdahulu hasil belajar dalam kompentensi pencatan dalam jurnal umum hasil belajarnya menunjukkan $31 \%$, dan dalam melakukan pencatan dalam jurnal penyesuaian $26 \%$, setelah diamati maka kurangnya hasil belajar tersebut disebabkan anak kurang mampu menetapkan akun debit dan akun kredit.Dalam penelitian ini untuk mengatasi solusi tersebut maka dirasa perlu untuk memberikan lembar kerja mahasiswa agar mahasiswa dapat melatih dirinya mengerjakan soal-soal akuntansi melalui model pembelajaran word square. Model pembelajaran word Square adalah model pembelajaran yang sangat menyenangkan dimana sianak asyik mengarsir kata-kata perkata melalui nama-nama akun yang sudah disusun sedemikian rupa. Huruf-huruf dalam pembelajaran word square tersebut adalah huruf-huruf yang berhubungan dengan akun laporan keuangan. Melalui lembar kerja mahasiswa ini diharapkan dapat meningkatkan hasil belajar. Dalam penelitian ini, peneliti melakukan pembelajaran dengan model word square, dan menggunakan strategi pembelajaran antara lain adalah strategi Learning Stars With a Quation. Dimana dalam strategi ini setiap masalah diawali dengan pertanyaan. Pertanyaan merupakan suatu motivasi dalam pembelajaran, dan selain dari pada itu untuk mengkolaborasikan peneliti menggunakan metode drill yaitu mahasiswa diwajibkan untuk mengerjakan tuugas-tugas akuntansinya. Untuk mengamati aktivitas anak dalam belajar peneliti dalam hal ini menyediakan lembar observasi yang berisikan pengamatan mengenai aktivitas-aktivitas dalam hal bertanya, mengerjakan latihanlatihan akuntansi, dan antusias dalam mengikuti pelaajaran. Serta keaktifan dalam bekerja dalam kelompoknya. Pengolahan data hasil belajar dilakukan dengan menggunakan metode persentase dari persentase tersebut lalu dianalisis untuk mengambil sebuah kesimpulan. Setelah dilakukan penelitian ada peningkatan hasil belajar sebelum diberlakukan pembelajaraan wordsquare dan setelah pembelajaran wordsquare yaitu hasil belajar $90 \mathrm{~s} / \mathrm{d} 100$ ada kenaikan $25 \%$ dan hasil belajar $70 \mathrm{~s} / \mathrm{d} 80$ ada kenaikan 42,5\%. Disamping
\end{abstract}

Keywords: LKM,wordsquare,hasil belajar 


\section{A. Pendahuluan}

\subsection{Latar belakang}

Permasalahan dalam penelitian adalah rendahnya hasil belajar akuntansi terutama dalam hal melakukan proses pencatatan yaitu proses jurnal. Proses jurnal adalah suatu proses pencatatan dimana mahasiswa dituntut harus dapat menentukan akun debit dan akun kredit sebagai dasar penyusunan laporan keuangan, dimana dalam hasil penelitian terdahulu hasil belajar mahasiswa dalam menentukan akun debit dan akun kredit dalam standard kompetensi jurnal umum belum mencapai nilai optimal, dimana dalam hasil penelitian tersebut hasil yang diperoleh mahasiswa sebesar $31 \%$ yang mendapatkan hasil belajar dalam kategori cukup. Dan $69 \%$ yang mendapatkan hasil belajar dibawah cukup.

Dalam menyelesaikan jurnal penyesuaian mahasiswa hanya mendapatkan hasil belajar $26 \%$ dalam kategori cukup dan $74 \%$ dalam katagori dibawah cukup serta dalam penyusunan neraca lajur dan laporan keuangan sudah memadai hasil belajarnya karena dalam proses penyusunan neraca lajur dan laporan keuangan hanya membutuhkan buah pikiran yang sederhana yaitu hanya proses pemindahan saja tanpa memproses analisis yang lebih tajam. Untuk lebih jelasnya dapat dilihat dari tabulasi data dibawah ini:

Tabel 1.1 Hasil Belajar Mahasiswa dalam mata kuliah Akuntansi keuangan Dasar

\begin{tabular}{|l|l|c|c|}
\hline No & Hasil Belajar & $\begin{array}{c}\text { Diatas } \\
\text { Nilai } \\
\text { Cukup } \\
\text { (C) }\end{array}$ & $\begin{array}{c}\text { Dibawah } \\
\text { Nilai } \\
\text { Cukup } \\
\text { ( C ) }\end{array}$ \\
\hline 1 & Jurnal Umum & $31 \%$ & $69 \%$ \\
\hline 2 & $\begin{array}{l}\text { Jurnal } \\
\text { Penyesuaian }\end{array}$ & $26 \%$ & $74 \%$ \\
\hline 3 & $\begin{array}{l}\text { Penyusunan } \\
\text { Neraca Lajur }\end{array}$ & $44 \%$ & $56 \%$ \\
\hline 4 & $\begin{array}{l}\text { Penyusunanlap } \\
\text { oran Keuangan }\end{array}$ & $50 \%$ & $50 \%$ \\
\hline 5 & $\begin{array}{l}\text { Pembuatan } \\
\text { Jurnal Penutup }\end{array}$ & $69 \%$ & $31 \%$ \\
\hline
\end{tabular}

Sumber : Hasil Penelitian

Berdasarkan tabel diatas dapat dilihat bahwa rata-rata nilai pembelajaran akuntansi, belum mendapatkan nilai yang optimal . hal ini berbagai macam yang mempengaruhi hasil belajar tersebut, salah satunya adalah kurangnya kemampuan mahasiswa dalam menjurnal selain dari pada latar belakang belajar semasa dibangku SMA, juga yang mempengaruhinya adalah karena tidak mampunya mahasiswa untuk melakukan 
proses jurnal terutama dalam hal mengenal nama akun.

Model pembelajaran wordsquare adalah suatu model yang memberikan solusi untuk dapat membantu mahasiswa lebih mengenal nama akun yang nantinya akan dapat menyusun laporan keuangan sesuai dengan prosedur yaitu melakukan jurnal umum, dengan menentukan debit dan kredit secara benar.

Rancangan lembar kerja dengan model pembelajaran wordsquare ini akan dapat memberikan solusi dalam meningkatkan hasil belajar mahasiswa, dimana istilah-istilah akuntansi dipaparkan secara terperinci dan juga proses analisis transaksi dan format format laporan keuangan akan disajikan didalamnya. Latihan-latihan yang disajikan secara berulang-ulang membuat kreatifitas mahasiswa untuk lebih memahami akuntansi baik dari segi mengenal nama akun maupun menyelesaikan masalah-lasalah akuntansi seperti pencatatan dalam jurnal umum, ayat jurnal penyesuaian penysusunan lneraca lajur maupun penyusunan laporan keuangan melalui neraca lajur dan jurnal penutup serta jurnal balik.

\section{B. Tinjauan Pustaka}

\section{Pengertian Lembar Kerja}

LKS (lembar kerja siswa) adalah materi ajar yang dikemas secara integrasi sehingga memungkinkan siswa mempelajari materi tersebut secara mandiri . LKS adalah lembar kerja yang berisikan informasi dan interaksi dari guru kepada siswa agar dapat mengerjakan sendiri suatu aktifitas belajar, melalui praktek atau penerapan hasil-hasil belajar untuk mencapai tujuan intruksional $^{1}$.jadi berdasarkan pengertian diatas lembar kerja mahasiswa adalah lembar kerja yang dikemas sedemikian rupa oleh guru, untuk membantu mahasiswa dalam memahami materi materi yang diberikan berdasarkan informasi-informasi guru dan dari hasil penyajian materi diberikan latihanlatihan yang harus dikerjakan secara mandiri

\section{Strategi pembelajaran.}

Strategi pembelajaran merupakan suatu serangkaian rencana kegiatan yang termasuk didalamnya penggunaan metode dan pemanfaatan berbagai sumber daya atau kekuatan dalam suatu

\footnotetext{
${ }^{1}$ Ratna Wilis Dahar (1986) Ratna Wilis Dahar (1986) mandiri http://wywld. wordpress.com/2009/11/14/model-pembelajaran -word-square.
} 
pembelajaran. Strategi pembelajaran disusun untuk mencapai suatu tujuan tertentu. Strategi pembelajaran didalamnya mencakup pendekatan, model, metode dan teknik pembelajaran secara spesifik. ${ }^{2}$

Strategi pembelajaran merupakan hal yang perlu diperhatikan guru dalam proses pembelajaran. Strategi pembelajaran adalah komponenkomponen dari suatu set materi termasuk aktivitas sebelum pembelajaran, dan partisipasi peserta didik yang merupakan prosedur pembelajaran yang digunakan kegiatan selanjutnya. $^{3} \quad$ Strategi pembelajaran merupakan perpaduan dari urutan kegiatan, cara mengorganisasikan materi pelajaran peserta didik, peralatan dan bahan, dan waktu yang digunakan dalam proses pembelajaran untuk mencapai tujuan pembelajaran yang telah ditentukan. ${ }^{4}$

Strategi yang digunakan dalam model pembelajaran ini adalah strategi pembelajaran yang berhubungan dengan

2 Menurut Hamzah B. Uno (2008:45) model pembelajaran menciptakan proses belajar mengajar yang kreatif dan efektif.Bumi Aksara. Jakarta.

\footnotetext{
${ }^{3}$ Dick dan Carey (2005:7)the systematic Design of Instruction third ed,florida Harper Collins Publisher.

${ }^{4}$ Suparman (1997:157).Analisis Pembelajaran..Depdikbud .Jakarta
}

tingkat pemahaman mahasiswa dalam bidang akuntansi dan strategi yang meningkatkan kreatifitas mahasiswa dalam melakukan pekerjaan yang berhubungan dengan akuntansi, karena akuntansi adalah suatu proses pencatatan yang memerlukan tingkat analisis yang tajam dan serius. Selain dari pada model pembelajaran wordsquare juga nanti nya akan dikolaborasikan metode yang tepat misalnya jenis strategi Learning Stars With a Quation. Menurut Strategi Learning Stars With a quation ( belajar memulai dengan sebuah pertanyaan ) dimana dalam pembelajaran ini fungsinya untuk merangsang siswa dalam bertanya dan memutar peran agar peserta didik dapat merespon pertanyaan yang dilontarkan kepada teman yang lainnya. ${ }^{5}$

Prosedur dalam pembelajaran aktif learning Starts with a quation adalah sebagai berikut :

1. mendistribusikan kepada peserta didik sebuah hand aou materi pelajaran pilihan (anda boleh menggunakan satu halaman dari satu buku tks) dari pada satu hand out) Kunci pemilihan materi

\footnotetext{
${ }^{5}$ Silberman Mei (1996 : 144)Pembelajaran aktif 101 strategi untuk mengajar secara aktif.jakarta Upi (1996:144)
} 
adalah kebutuhan untuk merangsang pertanyaan bagi sebagian pembaca.Selebaran yang memberikan informasi luas tapi kurang detail atau penjelasan yang dibatasi sangatlah sesuai. Sebuah grafik atau diagram yang menarik dan menggambarkan beberap disiplin ilmu merupakan pilihan yang baik.Teks yang terbuka untuk interpretasi juga pilihan yang baik dengan harapan untuk menimbulkan rasa ingin tahu.

2. Suruhlah peserta didik mempelajari selebaran tersebut membuat pengertian dari hand out sebagnyak mungkin dan identifikasi apa saja yang mereka tidak mengerti . dengan memberi tanda dokumen dengan pertanyaan-pertanyaan pada informasi yang tidak mereka mengerti, doronglah peserta didik memasukkan tanda Tanya sebanyak mungkin yang mereka harapkan

3. Berkumpul lagi dikelas,dan jawab pertanyaan peserta didik dengan tangkas. Anda mengajar dengan jawaban anda terhadap pertanyaan peserta didik dari pada melalui sebuah preset lesson atau jika anda ingin dengarlah seluruh pertanyaan dan kemudian ajarkan sebuah pressed lesson .butlah usaha khusus untuk merespons pertanyaan yang diajukan peserta didik.

Menurut peneliti strategi ini akan membantu untuk mengetahui kelemahan -kelemahan dari siswa dalam hal pembelajaran akuntansi terutama dalam mengenal nama akun,

Selain dari pada itu peneliti menggunakan model pembelajaran drill akan memudahkan siswa dalam memahami akuntansi dengan mengerjakan latihan-latihan. metode drill adalah merupakan suatu cara mengajar dengan memberikan latihanlatihan terhadap apa yang dipelajari siswa sehingga memperoleh suatu keterampilan tertentu . dengan langkahlangkah sebagai berikut:

a. siswa diberikan latihan soal perkalian bersusun satu angka dikalikan tiga angka secara terus menerus.

b. Siswa diminta menghafal perkalian seperti pada tabel perkalian sehingga siswa mudah dalam 
menyelesaikan soal perkalian bersusun

c. Siswa diberikan latihan soal perkalian bersusun dua angka dengan tiga angka.

d. Berdasarkan pendapat diatas maka dalam penelitian ini strategi untuk mengenal nama akun dengan model pembelajaran wordsquare cocok digunakan dengan metode dril

\section{Metode Penelitian}

Penelitian ini menggunakan metode Experimen yaitu suatu metode yang melakukan percobaan . dalam hal ini peneliti mencoba langsung terhadap pembelajaran yang akan dilakukan dengan mengunakan lembar kerja mahasiswa dengan model pembelajaran word square.Data yang akan dikumpulkan dalam penelitian ini adalah data mengenai pengembangan materi Akuntansi sesuai dengan Standard Kompetensi dan kompetensi dasar berdasarkan kurikulum yang berlaku pada Fakultas ekonomi ,antara lain adalah materi jurnal umum, jurnal penyesuaian, jurnal penutup, jurnal balik dan jurnal koreksi serta penyusunan laporan keuangan dengan neggunakan model pembelajaran wordsquare, selain dari pada itu hasil pengembangan Lembar Kerja Mahasiswa ini dijadikan suatu acuan dalam pembelajaran akuntansi dan selama proses pembelajaran dilihat perkembangan hasil pembelajaran yang disajikan setiap kompetensi dasar dan dibandingkan dengan hasil pembelajaran yang lalu apakah ada peningkatan atau tidak,Selain itu diperlukan lembar observasi untuk melihat aktifitas mahasiswa selama proses pembelajaran berlangsung dengan lembar observasi (terlampir).

Berdasarkan hasil tes belajar lalu dihimpun sedemikian rupa dan dilihat perbandinganya apakah ada peningkatan hasil belajar selain dari pada itu Instrumen penelitian yang telah terkumpul akan dianalisis dengan menggunakan metode diskriptif. Yaitu dalam bentuk persentase.

\section{Hasil Penelitian}

1. Hasil Survey Pendahuluan

Sebelum melakukan pembelajaran peneliti melakukan evaluasi terhadap hasil lembar kerja mahasiswa yang telah dirancang sedemikian rupa dan mendiskusikan kepada teman-teman sejawat untuk menerima masukan dari mitra kerja, demi kesempurnaan lembar 
kerja mahasiswa tersebut. Berdasarkan Hasil diskusi maka ada beberapa masukan yang peneliti terima antara lain adalah disain lembar kerja,Isi lembar kerja lebih disempurnakan lagi dengan pemaparan teori singkat mengenai pembelajaran yang akan dilakukan dan bentuk test beserta jawaban-jawabannya.

\section{Pemilihan objek penelitian}

Setelah peneliti menelaah kurikulum yang digunakan beberapa perguruan tinggi yang ada diKota Madya medan maka penelitian ini diuji cobakan pada mahasiswa Fakultas ekonomi Universitas Muhammadiyah Sumatera Utara, Seyogyanya penelitian ini akan dilakukan di fakultas keguruan dan ilmu pendidikan, tetapi pada awal masuk kelas peneliti melihat situasi dan kondisi dari pada mahasiswa fakultas keguruan tidak memungkinkan untuk dilakukan penelitian pada mahasiswa fakultas tersebut jadi peneliti memilih objek untuk dilakukan penelitian adalah pada fakultas ekonomi ,alasan peneliti mengambil objek penelitian pada fakultas ekonomi Universitas Muhammadiyah Sumatera Utara adalah disebabkan Fakultas ekonomi jumlah SKSnya, pada mata kuliah pengantar akuntansi adalah 6 SKS teori dan termasuk prakteknya, jadi dalam hal ini peneliti bebas untuk melaksanakan pembelajaran dengan menggunakan latihan-latihan pada lembar kerja mahasiswa,pembelajaran ini langsung peneliti bimbing dan amati kegiatannyanya selama pembelajaran berlangsung.

\section{E. Analisis Hasil Penelitian}

1. Deskripsi data awal penelitian

Sebelum penulis melakukan penelitian penulis disini mengobservasi keberadaan Mahasiswa sesuai dengan jenis kelamin dan latar belakang jurusan yang mereka ambil pada saat dibangku SLTA. Tujuan dari pada mengetahui latar belakang jurusan adalah untuk mengetahui kemampuan mahasiswa mengenai akuntansi. Berdasarkan hasil survey maka diperoleh data sebagai berikut:

Tabel 5.1

Jumlah Mahasiswa ditinjau dari latar belakang jurusan di SLTA

Dan Jenis Kelamin

\begin{tabular}{|l|l|c|c|c|c|}
\hline No & \multirow{2}{*}{$\begin{array}{c}\text { Jurusan } \\
\text { SLTA }\end{array}$} & \multicolumn{2}{|c|}{$\begin{array}{c}\text { Jenis } \\
\text { Kelamin }\end{array}$} & \multirow{2}{*}{ Jumlah } & $\%$ \\
\cline { 3 - 5 } & & Pria & Wanita & & \\
\hline 1 & IPA & 8 & 15 & 23 & $57,5 \%$ \\
\hline 2 & IPS & 2 & 13 & 15 & $37.5 \%$ \\
\hline 3 & SMK & 0 & 2 & 2 & $5 \%$ \\
\hline & & & & & \\
\hline & Jumlah & $\mathbf{1 0}$ & $\mathbf{3 0}$ & $\mathbf{4 0}$ & \\
\hline
\end{tabular}


Berdasarkan tabel di atas menunjukkan bahwa jumlah mahasiswa yang berasal dari latar belakang jurusan yang pernah mendapatkan pembelajaran akuntansi sebanya 42.5\%. Yaitu 37,5\% berasal dari jurusan IPS dan 5\% dari juruan SMK Bisnis.

Setelah melakukan survey terhadap jurusan yang diambil disekolah pada saat di bangku SLTA lalu penulis mengadakan tes awal untuk melihat kemampuan Siswa dalam mengenal nama Akun, sebelum melakukan tes awal penulis mengabsen peserta kuliah pada hari itu yang berjumlah 40 orang. Lalu langkah awal yang penulis lakukan adalah memberikan pengarahan kepada mahasiswa untuk melakukan pekerjaan bagaimana mereka bisa mengarsir dari huruf menjadi suatu kata yang berhubungan dengan nama akun. Nama akun terlebih dahulu dirancang sesuai dengan pembelajaran wordsquare, yaitu dengan langkah langkah sebagai berikut:

1. Guru menjelaskan tujuan pembelajaran.

2. Guru menunjukkan lembar peraga yang berisikotak word square dengan alternatif jawaban vertikal, diagonal. mahaiswa yang dapat menjawab pertanyaan ditugaskan mencari dan memberi tanda arsir pada kotak word square yang disediakan pada lembar peraga.

3. Guru membagikan LKS yang berisi wacana tentang nama akun dalam bentuk word square sebanyak 10 soal.

Bentuk Lembar Kerjanya adalah sebagai berikut:

\begin{tabular}{|c|c|c|c|c|c|c|c|c|c|}
\hline A & S & E & T & A & X & C & A & S & H \\
\hline C & U & Q & I & T & O & T & H & E & R \\
\hline C & P & U & T & I & L & I & T & Y & E \\
\hline O & L & I & N & T & R & E & S & T & N \\
\hline U & I & T & D & U & I & T & I & M & T \\
\hline N & E & Y & E & S & N & E & P & X & E \\
\hline T & U & N & E & A & R & N & E & D & I \\
\hline I & N & T & R & E & S & T & I & A & I \\
\hline
\end{tabular}

4. Siswa mengerjakan dalam waktu 30 menit.

5. Pada akhir kegiatan siswa menunjukkan jawaban word square Dari hasil jawaban berdasar hasil olahan data maka hasil yang diperoleh dari mahasiswa adalah sebagai berikut:

Tabel 5,2

Hasil test Awal Mahasiswa dalam mengarsir nama akun

\begin{tabular}{|l|l|l|l|}
\hline Hasil Test & F & $\%$ & Keterangan \\
\hline $9-10$ & 0 & 0 & Sangat Baik \\
\hline $7-8$ & 0 & 0 & Baik \\
\hline $5-6$ & 0 & 0 & Cukup \\
\hline $3-4$ & 20 & 47 & Kurang \\
\hline $1-2$ & 23 & 53 & Tidak Baik \\
\hline
\end{tabular}




\section{Jumlah}

\section{\begin{tabular}{l|l|}
43 & 100 \\
\hline
\end{tabular}}

Berdasarkan tabel diatas menunjukkan bahwa peserta kuliah masih kurang dalam mengenal nama akun dan dapat dilihat bahwa hasil yang diperoleh peserta kuliah adalah 20 orang yang dapat menjawab nama akun 3 s/d 4 dan 23 orang yang mendapatkan hasil arsiran nama akun1s/d 2 nama akun.

Setelah dapat hasil dari pengarsiran data tersebut diatas lalu mahasiswa diberikan tes awal untuk mengetahui kemampuan akuntansinya, antara lain yang berhubungan dengan jurnal umum,jurnal penyesuaian dan menyusun laporan keuangan hasilnya adalah sebagai beriku:

Tabel 5.3 Hasil tes Awal Akuntansi

\begin{tabular}{|c|c|c|c|}
\hline \multirow{2}{*}{$\begin{array}{c}\text { Hasil } \\
\text { belajar }\end{array}$} & $\begin{array}{c}\text { Jurnal } \\
\text { umum }\end{array}$ & $\begin{array}{c}\text { Jurnal } \\
\text { penyesuai } \\
\text { an }\end{array}$ & $\begin{array}{c}\text { Laporan } \\
\text { keuanga } \\
\text { n }\end{array}$ \\
\cline { 2 - 4 } frekuensi & frekuensi & frekuensi \\
\hline $90-100$ & 0 & 0 & 0 \\
\hline $70-80$ & 3 & 0 & 7 \\
\hline $50-60$ & 30 & 7 & 23 \\
\hline $30-40$ & 7 & 20 & 0 \\
\hline $10-20$ & 0 & 13 & 0 \\
\hline Jumlah & 40 & 40 & 40 \\
\hline
\end{tabular}

\section{Deskripsi Hasil Pelaksanaan Pembelajaran \\ a. Perencanaan Pembelajaran}

Melihat hasil dari test awal yang dilakukan, maka penulis melakukan rencana tindakan dengan merancang Pengembangan Pembelajaran yang dituangkan dalam satuan Acuan Pembelajaran. Dalam hal ini merancang kegiatan pembukaan , kegiatan inti dan kegiatan penutup, dengan menggunakan perangkat pembelajaran seperti media, dan bahan ajar.Dalam kegiatan Inti penulis menggunakan model pembelajaran disesuaikan dengan materi yang akan dilaksanakan dan bagian penutup penulis memberikan soal-soal yang dibawa pulang dan akan dilakukan Umpan baliknya dalam pembelajaran.(Data terlampir)

\section{b. Pelaksanaan tindakan.}

Pada pertemuan pertama penulis memaparkan rencana pembelajaran kepada peserta kuliah dengan mentayangkan melalui Infokus, yaitu Silabus dan Satuan Acuan Pembelajaran dan memberitahukan dahulu materi yang akan disajikan selama satu semester, Lalu melakukan kontrak kuliah agar peserta kuliah tahu hak dan kewajiban mereka dalam mengikuti kuliah. Setelah memaparkan Silabus maka selanjutnya dilakukan pembelajaran ,Pembelajaran ini dilakukan 14 kali pertemuan ditambah dengan 14 kali pertemuan lagi praktek akuntansi, tetapi sehubungan 
dengan penelitian mengenal nama akun penelti paparkan hanya pembelajaran nama akun yang berhubungan dengan pembelajaran wordsquare, antara lain adalah pembelajaran Struktur dasar akuntansi yang berhubungan dengan jurnal umum, Jurnal penyesuaian dan menyusun laporan keuangan.

1. Pembelajaran Jurnal Umum dengan model pembelajaran Word Square.

Mengingat hasil yang diperoleh mahasiswa melalui hasil test awal masih kurang menguasai nama akun maka terlebih dahulu penulis memberikan nama-nama akun yang akan mereka hapal,serta meminta kepada mahasiswa untuk mendownloud dari internet mencari nama akun yang belum ada dari nama-nama akun yang diberikan oleh staf pengajar. Setelah mereka menghapal , maka mereka diminta untuk membuat nama-nama akun dalam bentuk word square sesuai apa yang mereka ketahui dimana dalam pembelajaran ini mahasiswa diminta untuk merancang nama-nama akun yang mendatar dan menurun. Salah satu hasil rancangan yang dibuat oleh mahasiswa adalah sebagai berikut:

MENDATAR

1. Harta (eng).....
2. Aktiva yg tidak mengalami penyusutan......

3. Sisi kiri perkiraan.....

4. Akun yg dilaporkan dalam neraca adalah disebut juga akun.....

5. Salah satu unsur neraca.....

6. Kode akun yg menggunakan.....

7. Bentuk dua kolom....

8. Harta paling lancer....

9. Hak residual atas asset perusahaan setelah dikurangi semua kewajiban....

10. Pengeluaran untuk reparasi disebut

11. Timbul dari pelaksanaan aktivitas perusahaan yg biasa dan dikenal dengan sebutan antara lain......

12. Barang dagangan ,bahan baku,barang dalam proses menjadi barang jadi...

\section{MENURUN}

1. Harta paling lancar....

2. Sisi kanan perkiraan....

3. Daftar harta utang dan modal saat tertentu....

4. Ikatan akutansi Indonesia....

5. Bukti jual beli secara kredit....

6. Transaksi diakui dan dicatat serta pada saat terjadinya transaksi.....

7. End of month....

8. Buku besar (eng)...

9. Pengambilan uang tunai untuk kepentingan pribadi disebut...

10. Penghasilan (eng)...

11. Bagian dari laba usaha perseroan terbatas yg dibagikan kepada pemilik perusahaan...

12. Biaya (eng) 
Hasil rancangan tersebut adalah hasil jawaban dari apa yang sudah diarsir oleh mahasiswa dari pertanyaan mendatar dan menurun. Diharapkan dari hasil rancangan tersebut akan ada perbaikan nilai awal dari mahasiswa.

Langkah selanjutnya yang dilakukan adalah pemaparan Standar Kompetensi Struktur Dasar Akuntansi dan kompetensi dasar analisis akuntansi sebagai informasi, dimana dalam kompetensi dasar tersebut berisikan materi definisi akuntansi secara umum, para pemakai akuntansi,sejarah akuntansi,kegunaan informasi akuntansi dan profesi akuntansi, Jurnal umum sampai dengan menyusun laporan keuangan. Pemaparan kompetensi dasar analisis akuntansi sebagai informasi tidak menggunakan model pembelajaran wordsquare, tetapi dalam penyusunan laporan keuangan yang diawali dengan melakukan jurnal umum menggunakan pembelajaran wordsqua, adapun pembelajaran yang dilakukan adalah sebagai berikut:

- Merumuskan tujuan pembelajaran

- Tujuan pembelajaran adalah target yang akan dicapai dalam peroses pembelajaran

- Memaparkan isi materi
- Menetukan teknik dan strategi

- Pengelompokkan belajar

- Penentuan waktu

Setelah dilakukan penjelasan materi maka dilakukan test terhadap hasil belajar jurnal umum hasilnya dapat dilihat dari tabel dibawah ini

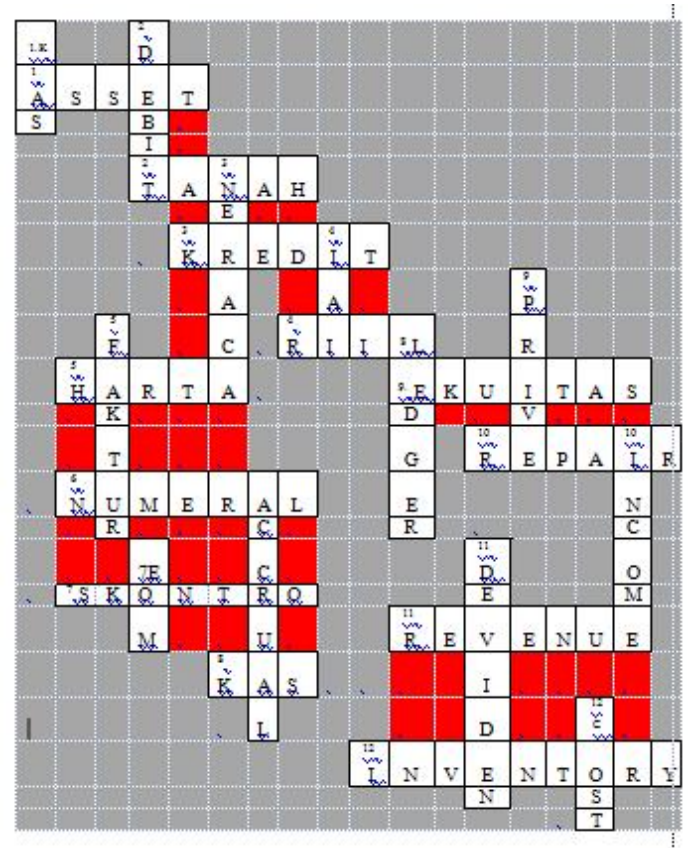

Tabel 5,4

Hasil tes Jurnal Umum

\begin{tabular}{|c|c|c|c|}
\hline Hasil Test & F & $\%$ & Keterangan \\
\hline $90-100$ & 0 & $0 \%$ & Sangat Baik \\
\hline $70-80$ & 15 & $37,5 \%$ & Baik \\
\hline $50-60$ & 23 & $57,5 \%$ & Cukup \\
\hline $30-40$ & 2 & $5 \%$ & Kurang \\
\hline $10-20$ & 0 & $0 \%$ & Tidak Baik \\
\hline Jumlah & 40 & $100 \%$ & \\
\hline
\end{tabular}

Dari tabel diatas hasil belajar jurnal umum 37,5\% berkatagori baik dan $57,5 \%$ berkatagori cukup dan $4 \%$ orang berkatagori kurang. 


\section{Pembelajaran Jurnal Penyesuaian dengan model pembelajaran Word Square}

Ayat jurnal penyesuaian adalah aktivitas untuk mengkoreksi akun sehingga laporan yang dibuat Berdasarkan akun tersebut dapat menunjukkan pendapatan, asset, dan kewajiban yang lebih sesuai. Ayat jurnal penyesuaian merupakan jurnal yang sering kali dibuat tidak berdasarkan aktivitas transaksi, tetapi berdasarkan keterangan atau informasi tertentu yaitu informasi yang diperoleh lalu dijadikan dasar untuk membuat akun tertentu yang terkait dengan informasi sehingga menyajikan informasi yang lebih sesuai. Dalam pembelajaran ayat jurnal penyesuaian dilakukan langkahlangkah sebagai berikut:

- Dosen memberikan pengertian apa itu jurnal penyesuaian

- Memberikan penjelasan pentingnya jurnal penyesuai dibuat bagi perusahaan

- Menjelaskan akun-akun yang perlu disesuaikan

- Meminta mahasiswa untuk menjawab dari pertanyaan yang diberikan yang berkenaan dengan jurnal penyesuaian dalam jangka waktu 5 menit, dan siapa yang dapat menjawab maka diberikan reward guna memotivasi mahasiswa sehingga mereka dapat berkompetisi untuk mendapatkan reward tersebut.

- Akhir perkuliahan mahasiswa diminta untuk membuat nama-nama akun dengan kompetensi jurnal penyesuaian, dimana mahasiswa diminta untuk dapat mendesain pertanyaan yang berhubungan dengan jurnal penyesuaian dan jawabannya kalau akun debit dibuat secara mendatar dan kalau akun kredit dibuat dengan menurun. Salah sati desain hasil dari mahasiswa adalah sebagai berikut

SOAL JURNAL PENYESUAIAN

1. Terdapat beban gaji yang harus dibayar sebesi(dicatat sebagai harta)

2. Perusahaan mitra membeli perlengkapan secara tunai sek(dicatat sebagai harta)

3. Perusahaan membayar asuransi sebesar Rp. 750.000 untuk 1 tahun (dicatat sebagai harta)

4. Listrik yang belum dibayar sebesar Rp. 100.000 (dicatat sebagai harta)

5. Beban bunga yang harus diperhitungkan sebesar Rp. 50.000 (dicatat sebagai harta)

6. Diterima sewa gedung untuk 2 tahun sebesar Rp. 2.000.000 (dicatat sebagai pendapatan)

7. Pekerjaan telah diselesaikan tetapi pembayaran belum diterima (dicatat sebagai beban)

8. Gedung disusutkan sebesar Rp. 3.000.000

9. Penyusutan peralatan reparasi sebesar Rp. 500.000 (dicatat sebagai harta)

10. Asuransi yang belum jatuh tempo sebesar Rp.300.000 (dicatat sebagai beban)

11. Piutang yang tidak dapat ditagih sebesar Rp. 1.000.000

12. Iklan yang telah kadaluarsa Rp. 62.000 (dicatat sebagai beban)

13. Pajak penghasilan ditaksir sebesar Rp. 1.300 .000

14. Persediaan supplies per 1 desember 2014 sebesar Rp. 400.000 (dicatat sebagai beban)

15. Diterima sewa gedung untuk 1 tahun sebesar Rp. 1.200.000 


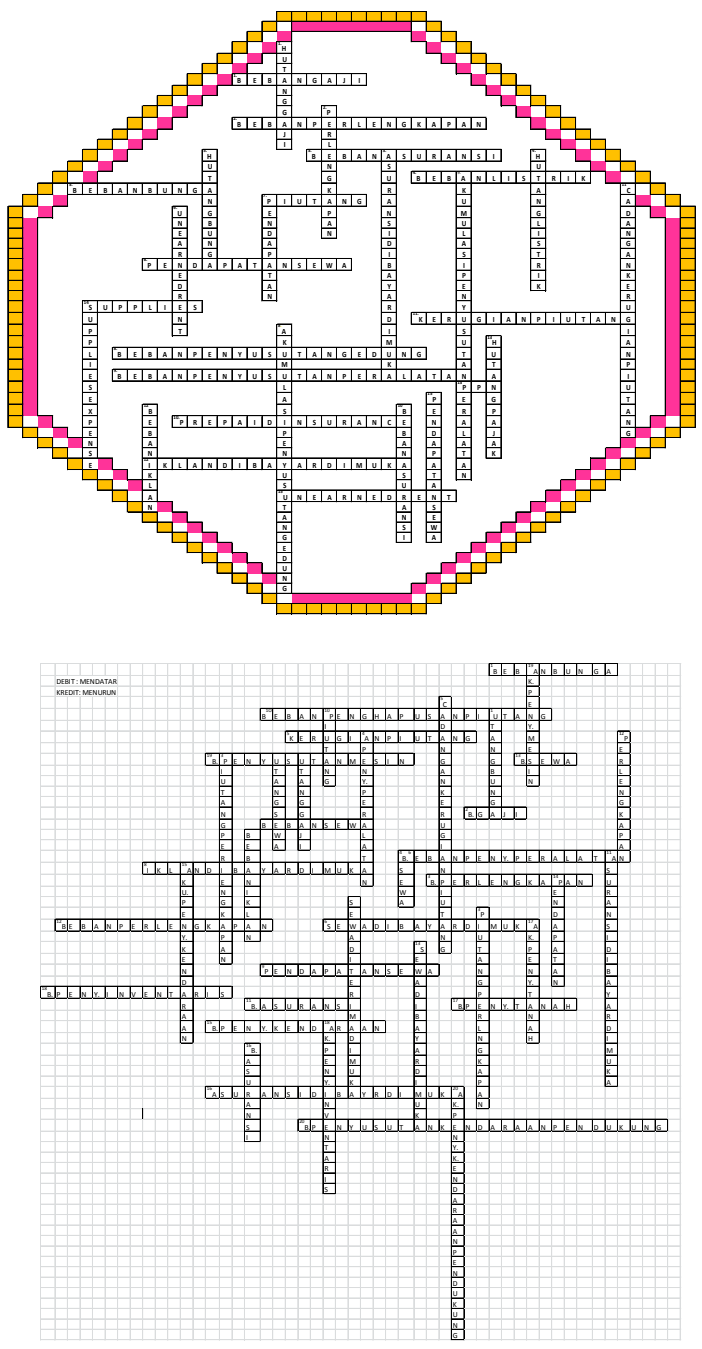

Setelah mahasiswa diminta untuk mendesain nama akun maka mahasiswa dilakukan evaluasi untuk mengetahui kemampuan mahasiswa dalam jurnal penyesuaian hasil dari evaluasi tersebut dapat dilihat dari tabel dibawah ini:

Tabel 5,5

Hasil tes Jurnal Penyesuaian

\begin{tabular}{|c|c|c|c|}
\hline Hasil Test & F & $\%$ & Keterangan \\
\hline $90-100$ & 2 & $5 \%$ & Sangat Baik \\
\hline $70-80$ & 38 & $95 \%$ & Baik \\
\hline $50-60$ & 0 & 0 & Cukup \\
\hline $30-40$ & 0 & 0 & Kurang \\
\hline $10-20$ & 0 & 0 & Tidak Baik \\
\hline
\end{tabular}

\section{\begin{tabular}{l|l|l|}
\hline Jumlah & 40 & $100 \%$ \\
\hline
\end{tabular}}

\section{Pembelajaan Menyusun laporan keuangan melalui model pembelajaran wordsquare}

Sebelum memberikan pembelajaran penyusunan laporan keuangan terlebih dahulu mahasiswa dituntut untuk dapat menguasai unsur-unsur yang terdapat dalam laporan keuangan. Laporan keuangan adalah merupakan informasi keuangan yang dibutuhkan berbagai pihak, yang digunakan sebagai dasar pengambilan keputusan ekonomi. Laporan keuangan tersebut terdiri dari laporan neraca, laba rugi, Laporan equitas,laporan arus kas dan catatan atas laporan keuangan, untuk mengetahui unsur-unsur laporan keuangan yang terdapat dalam laporan keuangan, dalam pembelajaran ini dilakukan dengan langkah-langkah sebagai berikut:

- Dosen menjelaskan pengertian laporan keuangan

- Dosen menjelaskan jenis laporan keuangan

- Dosen menjelaskan bentuk laporan keuangan

- Dosen menjelaskan tujuan dibuatnya laporan keuangan

- Dosen meminta kepada mahasiswa untuk dapat kedepan satu persatu 
menuliskan akun-akun yang terdapat dalam laporan neraca dan waktu disediakan untuk mahasiswa melakukannya adalah 5 menit.

- Dosen meminta kepada 20 orang mahasiswa untuk pertemuan hari pertama dalam menuliskan nama akun neraca yaitu akun aktiva dan akun passiva lalu dilanjutkan dengan kelompok kedua pada hari kedua sebanyak 20 orang.Penulis membagi dua kelompok disebabkan karena satu kali pertemuan hanya disediakan waktu sebanyak 150 menit, dimana 100 menit dilakukan untuk menuliskan kedepan nama akun dan 50 menit dilakukan untuk memberikan argumentasi dari jawaban mahasiswa. Dari 70 nama akun aktiva dan passiva maka diperoleh hasil sebagai berikut:

Tabel 5,6

Jumlah nama akun Aktiva dan Passiva yang diperoleh mahasiswa dalam mengisi unsur-unsur laporan keuangan

\begin{tabular}{|c|c|c|c|}
\hline $\begin{array}{c}\text { Jumlah } \\
\text { nama akun }\end{array}$ & $\mathbf{F}$ & $\%$ & Keterangan \\
\hline $66-79$ & 2 & $5 \%$ & Sangat Baik \\
\hline $52-65$ & 8 & $20 \%$ & Baik \\
\hline $38-51$ & 13 & $32,5 \%$ & Cukup \\
\hline $24-37$ & 14 & $35 \%$ & Kurang \\
\hline $10-22$ & 3 & $7,5 \%$ & Tidak Baik \\
\hline Jumlah & 40 & $100 \%$ & \\
\hline
\end{tabular}

Berdasarkan hasil tabel diatas menunjukkan bahwa dari 70 akun aktiva dan passiva, mahasiswa yang mendapatkan hasil tertinggi adalah sebanyak 2 orang yaitu dalam katagori sangat baik, dan hasil yang dalam katagori Baik sebanyak 8 orang atau 20 $\%$ dan dalam katagori cukup sebanyak 13 orang sebanyak $32,5 \%$.

Untuk laporan laba rugi,equitas, serta arus kas mahasiswa diminta untuk meneruskan dirumah sebagai pekerjaan rumah membuat nama akun sebanyakbanyaknya dari lapran keuangan tersebut.

Pertemuan selanjutnya mahasiswa dites untuk melihat kemampuaannya dalam menyusun laporan keuangan. Dari hasil evaluasi maka diperoleh hasil tes mahasiswa dalam menyusun laporan keuangan adalah sebagai berikut:

Tabel 5,7

Hasil tes penyusunan laporan keuangan

\begin{tabular}{|c|c|c|c|}
\hline $\begin{array}{c}\text { Jumlah } \\
\text { nama akun }\end{array}$ & $\mathbf{F}$ & $\%$ & Keterangan \\
\hline $90-100$ & 31 & $77,5 \%$ & Sangat Baik \\
\hline $70-80,9$ & 9 & $22,5 \%$ & Baik \\
\hline $50-60,9$ & 0 & $56 \%$ & Cukup \\
\hline $30-40,9$ & 0 & $4 \%$ & Kurang \\
\hline $10-20,9$ & 0 & $0 \%$ & Tidak Baik \\
\hline Jumlah & 40 & $100 \%$ & \\
\hline
\end{tabular}

Berdasakan tabel diatas dapat dilihat bahwa mahasiswa dalam menyusun 
laporan keuangan dengan menggunakan model pembelajaran wordsquare mendapatkan hasil belajar 77,5\% sangat baik.

\section{F. Observasi Tindakan}

Selama berlangsungnya pelaksanaan pembelajaran penulis dibantu oleh seorang observer untuk melakukan pengamatan aktivitas 40 mahasiswa hasil pengamatannya adalah sebagai berikut:

Aktivitas mahasiswa dalam mengikuti perkuliahan rata-rata sebesar 95\% , dalam memahami tugas masingmasing kelompok sebesar 97,5\% aktif dalam mengerjakan tugas $87,5 \%$ dan keaktifan dalam menjawab pertanyaan sebesar $70 \%$, keaktifan dalam menghimpun diskusi sebesar $70 \%$ serta keaktifan dalam bertanya sebesar $80 \%$.

\section{G. Refleksi}

\section{Setelah} pelaksanaan

pembelajaran dilakukan dan sudah mendapatkan hasil serta diamati segala kegiatan mahasiswa maka langkah selanjutnya dilakukan umpan balik terhadap mahasiswa pada ujian mid semester dan ujian semestar, dimana dalam ujian semester mahasiswa diuji kemampuan mulai menjurnal sampai dengan menyusun laporan keuangan dan dalam ujian semester mereka juga menyusun laporan keuangan melalui neraca lajur.

Hasil Ujian semester dapat dilihat dari tabel dibawah ini :

Tabel 5.8 Hasil Akhir Mahasiswa

Dalam pembelajaran wordsquare.

Hasil tes penyusunan laporan keuangan

\begin{tabular}{|c|c|c|c|}
\hline Tes Akhir & $\mathbf{F}$ & $\%$ & $\begin{array}{c}\text { Keteranga } \\
\mathbf{n}\end{array}$ \\
\hline $85-100$ & 9 & $22,5 \%$ & $\begin{array}{c}\text { Sangat } \\
\text { Baik }\end{array}$ \\
\hline $80-84$ & 12 & $30 \%$ & Baik \\
\hline $70-74$ & 9 & $22,5 \%$ & Cukup Baik \\
\hline $65-69$ & 10 & $25 \%$ & Cukup \\
\hline$>65$ & 0 & $0 \%$ & Tidak Baik \\
\hline Jumlah & 40 & $100 \%$ & \\
\hline
\end{tabular}

Dari hasil ujian akhir diatas menunnjukkan bahwa nilai dalam katagiru sangat baik sebanyak 22,5\%, nilai dalam katagiru baik sebanyak 39\%,dalam katagiri cukup baik sebanyak $25 \%$ dan dalam katagori cukup sebanyak $25 \%$.

\section{H. Pembahasan}

Berdasarkan hasil penelitian yang sudah dipaparkan diatas Model pembelajaran word square sangat membantu dalam memahami akuntansi khususnya dalam hal penyusunan laporan keuangan, hal tersebut dapat 
dilihat dari perkembangan hasil belajar mahasiswa sebelum dilakukan pembelajaran dan sesudah dilakukan pembelajaran mendapatkan hasil belajar diatas 70 adalah sebanyak $7,5 \%$ yaitu 3 orang tetapi setelah dilakukan pembelajaran mendapatkan hasil sebesar $75 \%$ atau 30 orang, ini berartia ada peningkatan hasil belajar setelah dilakukan model pembelajaran dengan model wordsquare

Dari tabel pelaksanaan pembelajaran yang dilakukan siklus pembelajaran menyusun laporan keuangan $77,5 \%$ berkatagoti sangat baik. Disamping itu dalam penerapan model pembelajaran pada jurnal penyesuaian mahasiswa dapat menguasai materi pembelajaran dengan hasil baik. Model pembelajaran wordsquare juga memberikan motivasi bagi mahasiswa untuk memiliki minat belajar dan aktivitas mahasiswa juga bertambah, dimana proses pembelajaran dosen selalu memberikan motivasi dalam hal kompetisi untuk menjawab pertanyaan yang diajukan dalam jangka waktu yang sudah ditentukan, dalam pemberian kompetisi tersebut mahasiswa juga senang karena siapa yang bisa menjawab akan diberika reward, sehingga dalam pembelajaran wordsquare mahasiswa berlomba-lomba untuk menguasai bahan ajar yang diberikan kepada mereka.

Pembelajaran dengan model worsquare dapat melibatkan mahasiswa secara keseluruhan, mahasiswa dapat mengembangkan imajinasinya dalam menyusun kata-kata yang sesuai dengan pembahasan, disamping itu siswa dapat mendesain bentuk wordsquare sesuai dengan keahlian mereka ,dengan background yang beraneka ragam sesuai seni yang mereka miliki. Pembelajaran wordsquare ini juga didukung oleh hasil peneliti dari Saptono (2003) yang mengatakan bahwa pembelajaran word square dapat meningkatkan keaktifan dan keterlibatan siswa dalam kegiatan belajar mengajar .

Dari keseluruhan hasil belajar mahasiswa belum mencapai ketetapan yang yang sudah ditarget oleh peneliti dimana target penilai yang sudah ditetapkan adalah sebagai berikut:

Tabel 6.0 Hasil akhir dan target penilaian

\begin{tabular}{|l|c|c|c|}
\hline & $\begin{array}{c}\text { Target } \\
\text { peneliti }\end{array}$ & Hasil & Varians \\
\hline Kehadiran & $95 \%$ & $95 \%$ & $0 \%$ \\
\hline Keaktifan & $95 \%$ & $95 \%$ & $5 \%$ \\
\hline Kelulusan & & & \\
\hline $\begin{array}{l}\text { Hasil } \\
\text { belajar }\end{array}$ & & & \\
\hline A & $75 \%$ & $22,5 \%$ & $(52,5 \%)$ \\
\hline
\end{tabular}




\begin{tabular}{|l|c|c|c|}
\hline $\mathrm{B}$ & $15 \%$ & $52,5 \%$ & $37,5 \%$ \\
\hline $\mathrm{C}$ & $10 \%$ & $25 \%$ & $15 \%$ \\
\hline
\end{tabular}

Berdasarkan tabel diatas penunjukkan ada kelemahan dalam pembelajaran dimana waktu pembelajaran yang dilakukan selama berlangsungnya pembelajaran adalah tergantung kepada waktu proses belajar mengajar yang ditetapkan oleh fakultas, sehingga perlakuan yang dibuat kepada mahasiswa tidak seragam dan akan adanya selang waktu sehingga anak yang belum mendapatkan kesempatan untuk untuk lebih berkreatif terpaksa menunggu pertemuan berikutnnya. Disamping karakter mahasiswa tidak sama antara satu dengan yang lain. Gaya belajar anak juga berbeda-beda.

\section{Kesimpulan}

Berdasarkan hasil penelitian maka dapat disimpulkan

1. Lembar kerja mahasiswa dengan model pembelajaran wordsquare akan lebih cepat mengenal Nama akun

2. Lembar kerja dengan Model Pembelajaran wordsquare dapat membantu mahasiswa dalam meningkatkan motivasi belajar
3. Model Pembelajaran wordsquare dapat meningkatkan aktivitas ma hasiswa

4. Mahasiswa dapat mengembangkan imajinasinya dengan untuk membuat arsiran sesuai dengan apa yang diinginkannya

5. Model pembelajaran worsquare dapat membantu dosen dalam merancang pembelajaran

6. Lembar Kerja mahasiswa membantu dosen dalam penyampaian pembelajaran

7. Hasil belajar mahasiswa terdapat peningkatan setelah mendapatkan pembelajaran dengan lembar kerja mahasiswa melalui model pembelajaran wordsquare

\section{Daftar Pustaka}

Benny A.Pribadi.(2009). Langkah Penting merancang kegiatan peembelajaran yang efektif dan berkualitas.Dian Rakyat.Jakarta.

Dick dan Carey (2005:7)the systematic Design of Instruction third ed,florida Harper Collins Publisher.

Hamzah.B.Uno,2008.model pembelajaran menciptakan proses belajar 
mengajar yang kreatif dan

efektif.Bumi Aksara. Jakarta.

Majid, abdul. 2006. Perencanaan pembelajaran, Rosdakarya:

bandung

Majid, Abdul. Perencanaan

Pembelajaran: Mengembangkan

Standar Kompetensi Guru.

Bandung: PT Remaja Rosdakarya

Mulyasa, Enco,2006. Kurikulum Tingkat

satuan Pendidikan. Rosdakarya.

Bandung.

Munawir,1997. Analisa Laporan

Keuangan. Liberty. Yogyakarta.

Bandung

Ratna Wilis Dahar (1986) mandiri

http://wyw1d.wordpress.com/2009/11/14/

model-pembelajaran-word-square

Sani abdullah Ridwan.2014.Pembelajaran

Saintifik untuk kurikulum

2013..Bumi Aksara. Jakarta.

Soekartawi, 2003. Prinsip Dasar e-

Learning dan Aplikasinya di

Indonesia, Jurnal Teknodik Vol.

VII No. 12.

Soekartawi, A. Haryono dan F. Librero, 2002, Greater Learning

Opportunities Through Distance

Education: Experiences in

Indonesia and the Philippines.
Southeast Journal of Education, December 2002.

Sutikno, M. Sobry. 2009. Pengelolaan Pendidikan: Tinjauan Umum dan Konsep Islami. Bandung: Prospect , 2004. Prospek Komputer Sebagai Media Pembelajaran Interaktif dalam Sistem Pendidikan Jarak Jauh di Indonesia, Jurnal Pusat Studi Indonesia, Vol. 8 No. 2.

James, warren,jonathan. 2009. Pengantar Akuntansi Adaptasi Indonesia.Salemba empat.Jakarta.

Pribadi, Benny \& Rosita, A. Tita, 2004. Prospek Komputer Sebagai Media Pembelajaran Interaktif dalam Sistem Pendidikan Jarak Jauh di Indonesia, Jurnal Pusat Studi Indonesia, Vol. 8 No. 2.

Rudianto, 2012. Pengantar Akuntansi konsep dan teknik penyusunan laporan

keuangan.Erlangga.Jakarta.

Rusmono dan Bambang Suharmantri, 2002. Pembelajaran Berbasis Web dan Komputer (Computer and Web-Based Instruction), Teknodik Vol. VI No.11.

Soemarso, 2004. Akuntansi suatu pengantar.Salemba empat.Jakarta 


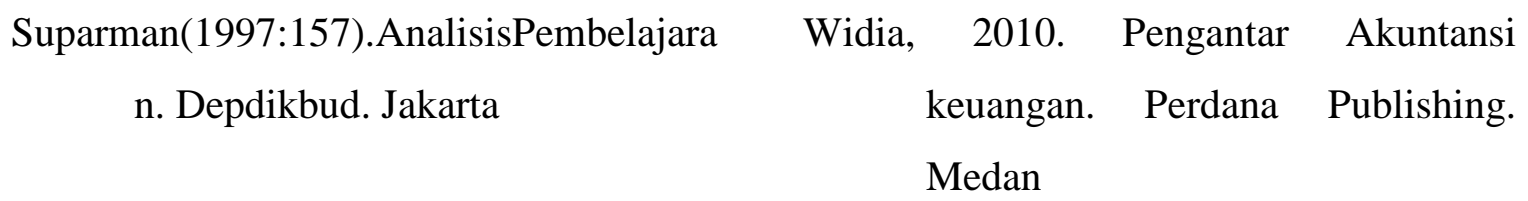

